Section Editor

Mitchell S.V. Elkind, MD, MS

Michael Strupp, MD

Sebastian von Stuckrad-

Barre, MD

Thomas Brandt, MD,

FRCP

Joerg Christian Tonn,

MD

Correspondence to

Dr. Strupp:

Michael.Strupp@med.uni-

muenchen.de

\section{Figure MRI}
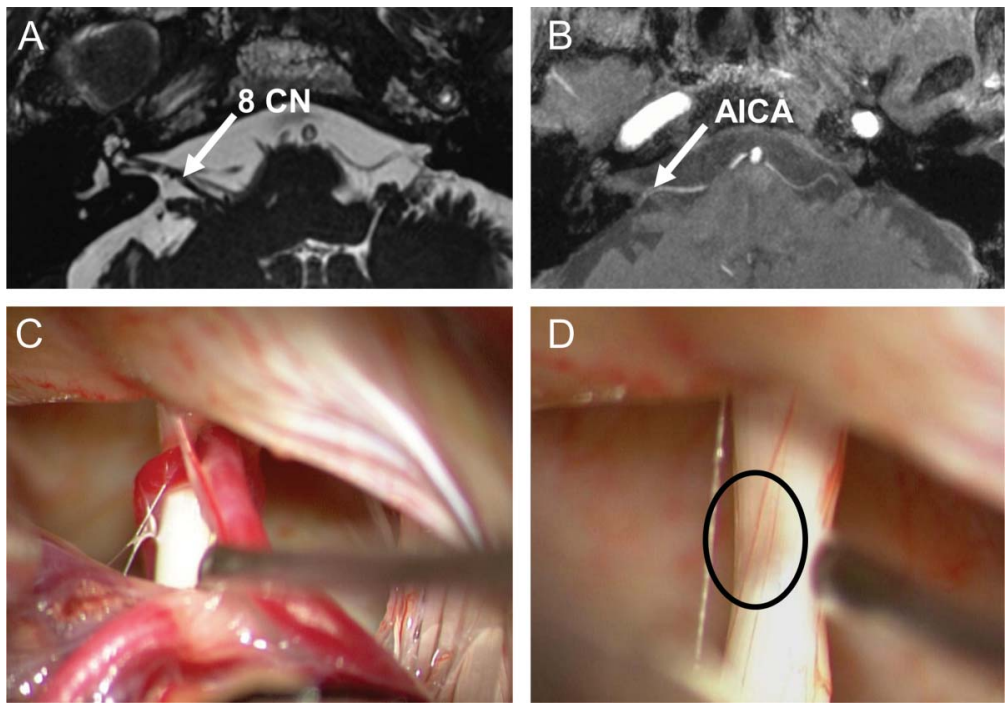

Cranial MRI (A: constructive interference in steady-state sequence, B: time-of-flight) shows contact (arrows) between the right eighth cranial nerve (CN) and the anterior inferior cerebellar artery (AICA). Intraoperative micrographs demonstrate vascular contact (C) and considerable compression of the eighth nerve after removal of the arteries $(D$, circle). diagnosed. ${ }^{1,2}$ Carbamazepine resolved the symptoms but the patient discontinued it due to side effects. The symptoms recurred, and surgery was performed. Intraoperatively, compression of the eighth nerve was found (figure, $\mathrm{C}$ and $\mathrm{D}$ ). He has had no further symptoms and takes no medication. These findings support the view that vascular compression of the root entry zone of the eighth cranial nerve can cause vestibular paroxysmia.

\section{AUTHOR CONTRIBUTIONS}

M. Strupp: drafting the manuscript for content, including medical writing and idea for the case report. S. von Stuckrad-Barre: initial examination and treatment of the patient, drafting the manuscript for content. T. Brandt: discussion of the case, drafting the manuscript, including medical writing. J.C. Tonn: operation of the patient, taking micrographs, drafting the manuscript for content, including medical writing.

\section{ACKNOWLEDGMENT}

The authors thank Dr. Jennifer Linn for evaluation of the MRI scans.

\section{STUDY FUNDING}

Institutional (German Ministry of Education and Research [BMBF]) grant 01EO0901 to the IFB, German center for vertigo and balance disorders at the University of Munich, Campus Grosshadern, Germany.

\section{DISCLOSURE}

M. Strupp is supported by grants from BMBF no. 01EO0901 to the $\mathrm{IFB}^{\mathrm{LMU}}$ and the BMBF and DFG. S. von Stuckard-Barre reports no disclosures. T. Brandt is supported by grants from BMBF no. 01EO0901 to the IFB ${ }^{\mathrm{LMU}}$. J.C. Tonn reports no disclosures. Go to Neurology.org for full disclosures.

\section{REFERENCES}

1. Brandt T, Dieterich M. Vestibular paroxysmia: vascular compression of the eighth nerve? Lancet 1994;343:798-799.

2. Hufner K, Barresi D, Glaser M, et al. Vestibular paroxysmia: diagnostic features and medical treatment. Neurology 2008;71:1006-1014. 


\section{Neurology}

\section{Teaching NeuroImages: Compression of the eighth cranial nerve causes vestibular paroxysmia}

Michael Strupp, Sebastian von Stuckrad-Barre, Thomas Brandt, et al. Neurology 2013;80;e77

DOI 10.1212/WNL.0b013e318281cc2c

\section{This information is current as of February 11, 2013}

Updated Information \& Services

References

Subspecialty Collections

Permissions \& Licensing

Reprints including high resolution figures, can be found at: http://n.neurology.org/content/80/7/e77.full

This article cites 2 articles, 1 of which you can access for free at: http://n.neurology.org/content/80/7/e77.full\#ref-list-1

This article, along with others on similar topics, appears in the following collection(s):

All Neurotology

http://n.neurology.org/cgi/collection/all_neurotology

MRI

http://n.neurology.org/cgi/collection/mri

Tinnitus

http://n.neurology.org/cgi/collection/tinnitus

Vertigo

http://n.neurology.org/cgi/collection/vertigo

Information about reproducing this article in parts (figures,tables) or in its entirety can be found online at:

http://www.neurology.org/about/about_the_journal\#permissions

Information about ordering reprints can be found online:

http://n.neurology.org/subscribers/advertise

Neurology ${ }^{\circledR}$ is the official journal of the American Academy of Neurology. Published continuously since 1951, it is now a weekly with 48 issues per year. Copyright @ 2013 American Academy of Neurology. All rights reserved. Print ISSN: 0028-3878. Online ISSN: 1526-632X.

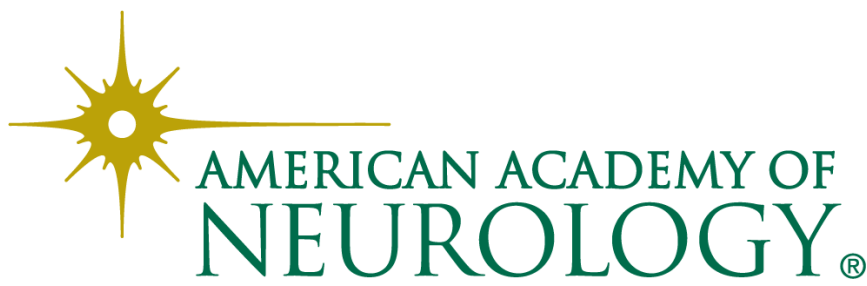

